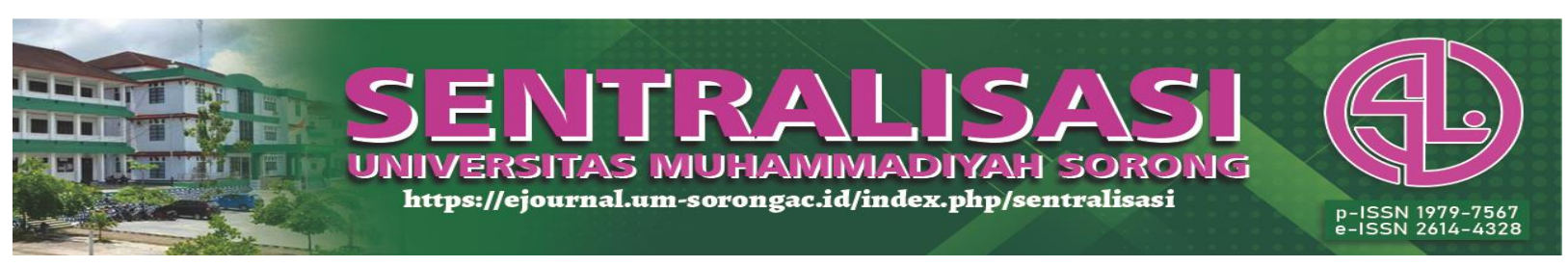

\title{
An Analysis on the Effects of NPL, NIM, LDR on Profitability Level and Stock Returns in Conventional Banks Listed in the Main Board of Indonesia Stock Exchange in The Period of 2014-2018
}

\author{
Dewi Oktary ${ }^{1}$, Rurin Pratiwi \\ ${ }^{1,2}$ Sekolah Tinggi Ilmu Ekonomi Indonesia Pontianak, Indonesia \\ E-mail : dewyoktari@gmail.com
}

direvisi: 29/12/2020 dipublikasikan: 31/01/2021

\begin{abstract}
Abstrak. Mengetahui pengaruh NPL, NIM, LDR, terhadap Tingkat Profitabilitas dan Return Saham adalah tujuan dari penelitian ini. Sampel yang digunakan sebanyak 24 bank konvensional yang tercatat di papan utama BEI tahun 2014- 2018.Teknik analisis data adalah analisis jalur dan Uji Sobel. Hasil yang didapat dalam penelitian ini adalah NPL berpengaruh negative signifikan terhadap profitabilitas dan return saham, NIM berpengaruh signifikan positif terhadap tingkat profitabilitas dan return saham sedangkan LDR tidak berpengaruh signifikan terhadap tingkat profitabilitas tetapi berpengaruh signifikan negative terhadap return saham. Tingkat Profitabilitas tidak berpengaruh signifikan terhadap return saham. NPL, NIM, LDR secara simultan berpengaruh signifikan terhadap Profitabilitas. Selain itu NPL, NIM, LDR, Tingkat Profitabilitas secara simultan berpengaruh signifikan terhadap return Saham. NPL, NIM, LDR tidak berpengaruh secara signifikan terhadap return saham melalui profitabilitas
\end{abstract}

Kata kunci: NPL, NIM, LDR, Profitabilitas, Return Saham

\begin{abstract}
To find out the effects of NPL, NIM, LDR on the profitability level and stock returns is the aim of this study. The samples used were 24 conventional banks listed on IDX main board in 2014- 2018. The techniques of data analysis were path analysis and Sobel test. The results obtained in this study were that NPL had a significant negative effect on profitability and stock returns, NIM had a significant positive effect on the profitability level and stock returns, while LDR had no significant effect on the profitability level but it had a significant negative effect on stock returns. Profitability level had no significant effect on stock returns. NPL, NIM, LDR simultaneously had a significant effect on profitability. In addition, NPL, NIM, LDR and Profitability Level simultaneously had a significant effect on stock returns. NPL, NIM, LDR had no significant effect on stock returns. NPL, NIM, LDR had no significant effect on stock returns through profitability.
\end{abstract}

Keywords : NPL, NIM, LDR, Profitability, Stock Return

\section{Introduction}

In conducting their activities, banks certainly have some risks. One of the risks faced by banks is that banks must be ready for the occurrence of non-performing loans distributed to customers. To assess the total of non-performing loans, the NPL ratio can be used. According to Masyhud, 2004: 77 in (Muhamad, 2015) Non-Performing Loans (NPL) is one of the ways to measure the risk of banking business by looking at the total of non-performing loans in the banks. NPL ratio shows the numbers of non-performing loans. The higher the NPL, the worse the banking performance is. 


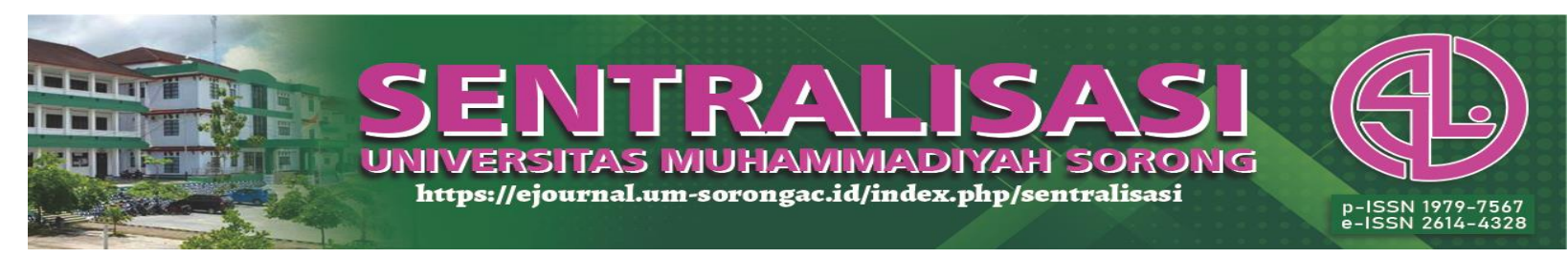

Banking in Indonesia, besides functioning to save funds, it also has to be profit-oriented. According to (Kasmir, 2018), in the conventional banking business, the main profit is generated from the difference between the saving interest given and the loan interest distributed. As for the NIM ratio, it can be used to figure out the amount of earned interest profit. According to (Rivai et al., 2013) NIM is the ability of productive assets to earn net interest income.

In addition, in the banking industry, there is also an important ratio to assess banking health and performance, namely LDR. According to Rivai et al (2013) Loan Deposit Ratio (LDR) is a comparison of the total credit provided by a bank and funds received by a bank which can be used to see the bank's ability to repay the fund withdrawals by the depositors who rely on the credit provided as a source of liquidity. LDR ratio shows the total funds from the third parties used to provide loans. A higher LDR shows that the company does not have sufficient liquidity to cover obligations to customers.

Based on the records (Financial Services Authority, 2019), bank gross NPL in 2018 was $2.33 \%$ smaller than in 2017 , which was $2.50 \%$. It means that bank management was able to manage non-performing loans in 2017 so that it had a decrease by $0.17 \%$ of non-performing loans in 2018. While based on the record (Financial Services Authority, 2019), the NIM of banks in 2018 was $5.14 \%$, which experienced a decrease compared to 2017 NIM which was at $5.32 \%$. This shows that the net interest obtained in the banking industry in 2018 decreased by $0.18 \%$ compared to 2017. The banking LDR in 2018 was $94.78 \%$ which was the highest value in the last 10 years, while the LDR in 2017 was $90.04 \%$.

Assessing company performance is highly important in which one of the ways is by looking at the profitability level of the bank. Profitability is the profit obtained from the running business. One of the analyses of profitability which can be used in this study is Return On Assets (ROA). According to (Rivai et al., 2013) ROA is used to measure bank's ability to gain overall profits. Meanwhile, according to (Financial Services Authority, 2019), ROA of Banking in 2018 was $2.55 \%$, it had an increase compared to 2017 with $2.45 \%$ ROA. Some companies engaged in banking sector continue to increase their profitability.

The decreasing value of NPL has an impact on the value of ROA which experiences an increase. A prior study related to this research shows different results. (Nadi, 2017), (Eprima, Nyoman, \& Gede, 2015) the results of their research shows that NPL had a significant negative effect on ROA and (Hutagalung, N.E.D and Ratnawati, 2013) the results of their research show that NPL had a significant effect on ROA, whereas ( Muhamad, 2015) the results of his research state that NPL did not have a significant effect on profitability. The NIM value has decreased from 2017 to 2018 but the ROA value had increased from 2017 to 2018. While the research (Nadi, 2017) and (Eprima et al., 2015) shows that NIM had a significant positive effect on ROA and the research (Hutagalung, NE D and Ratnawati, 2013) indicates that NIM had an effect on ROA. 


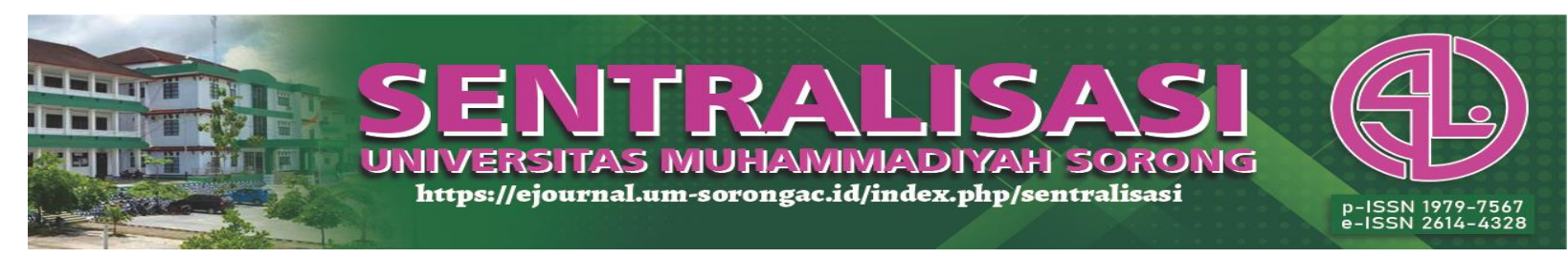

The value of LDR in 2018 had an increase compared to 2017 but the value of ROA also increased in 2018. The research (Eprima et al., 2015) reveals that LDR did not have a significant effect on ROA. Meanwhile, ROA or profitability also had an effect on the resulted stock returns. As for the prior research conducted by (Maftuhah, 2015) shows that NIM had an effect on stock returns, LDR had a significant positive effect on stock returns and LDR had a significant negative effect on stock returns, while a research (Zakchona \& Sihombing, 2019) shows that partially NPL , NIM, and ROA had no significant positive effect on bank stock returns and LDR had a significant negative effect on stock returns. The research conducted by (Muhamad, 2015) states that NPL and profitability had an effect on stock returns.

This study aims to find out the effects of NPL, NIM, and LDR on profitability level and stock returns. The selection of the three ratios was based on the significance of those three ratios, and they were because NPL, NIM, LDR were ratios related to the banking industry which were used to measure the profitability level and financial performance in determining stock returns. In addition, some of the ratios above can affect profitability and stock returns used by investors to find information before investing.

\section{Research Method}

This research is a causal research. The population used was 27 conventional commercial banks listed in the main board of IDX. The sampling technique in this study was purposive sampling. The consideration of sample taking in this study was conventional banking companies listed in the main board of IDX in 2014-2018 and published complete financial summaries so that 24 banks could be taken as the sample. This study uses secondary data, which is the company financial reports investigated by downloading directly on www.idx.co.id website.

The research variables used as exogenous variables were: NPL, NIM, LDR. The intermediate endogenous variable was profitability and the dependent/independent endogenous variable was stock returns. Meanwhile, the analysis tool used was SPSS V. 21 and the hypothesis testing technique used path analysis. Hypothesis testing also used the Sobel test to find out the significance of the intervening variables.

The framework of thinking in this study is:

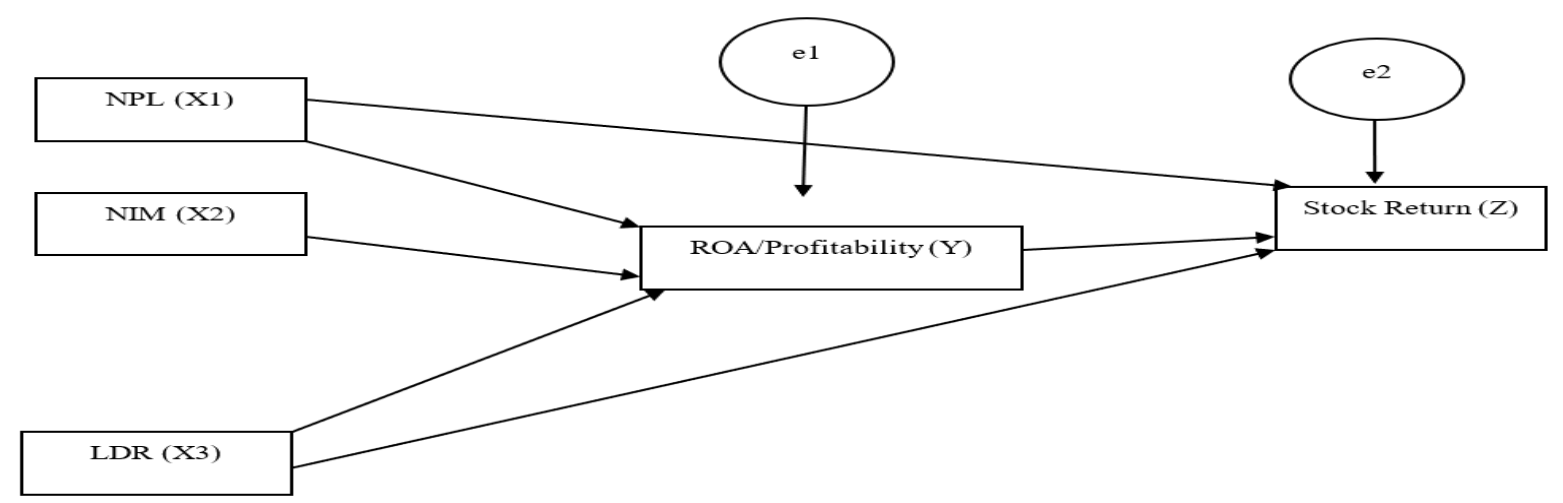

Figure 1. Framework of thinking 


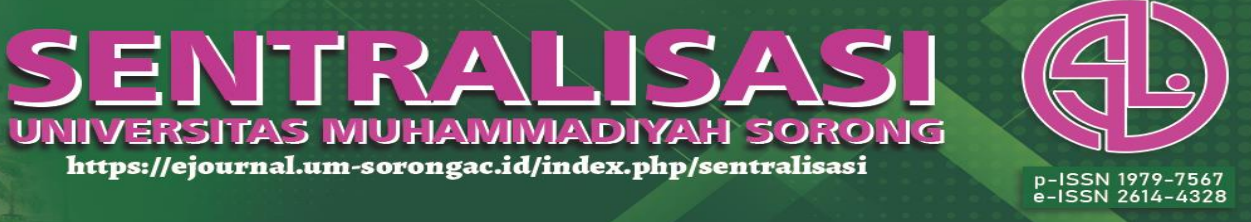

\section{Result dan Discussion}

\section{Statistical Description}

Table 1. Statistical Description

\begin{tabular}{cccccc}
\hline Annotation & N & Minimum & Maximum & Mean & Dev Standard \\
\hline NPL (X1) & 120 & 0,60 & 8,80 & 2,8294 & 1,42048 \\
NIM (X2) & 120 & 1,50 & 12,00 & 5,6309 & 2,00767 \\
LDR (X3) & 120 & 54,00 & 145,30 & 87,7400 & 11,72609 \\
ROA (Y) & 120 & $-4,90$ & 4,70 & 1,9203 & 1,25183 \\
Stock Return (Z) & 120 & $-68,82$ & 349,01 & 14,2494 & 54,98559 \\
Valid N (listwise) & 120 & & & &
\end{tabular}

\section{Source: Processed data}

Table 1 shows the statistical descriptive analysis for each variable, they are: NPL, NIM, LDR, ROA, and Stock Return. It can be seen in the table above that the NPL (X1) had a minimum value of 0.60 , the maximum was 8.80 , the mean was 2.8294 with a standard deviation of 1.42048 . The NIM variable (X2) had a minimum value of 1.50 , the maximum was 12.00 , the mean was 5.6309 with a standard deviation of 2.00767. The LDR variable (X3) had a minimum value of 54.00 , the maximum was 145.30 , the mean was 87.7400 with a standard deviation of 11.72609 . The ROA (Y) variable had a minimum value of -4.90 , the maximum was 4.70 , the mean was 1.9203 with a standard deviation of 1.25183 . The variable of Stock Return $(\mathrm{Z})$ had a minimum value of -68.82 , the maximum was 349.01 , the mean was 14.2494 with a standard deviation of 54.98559.

\section{Path Coefficient}

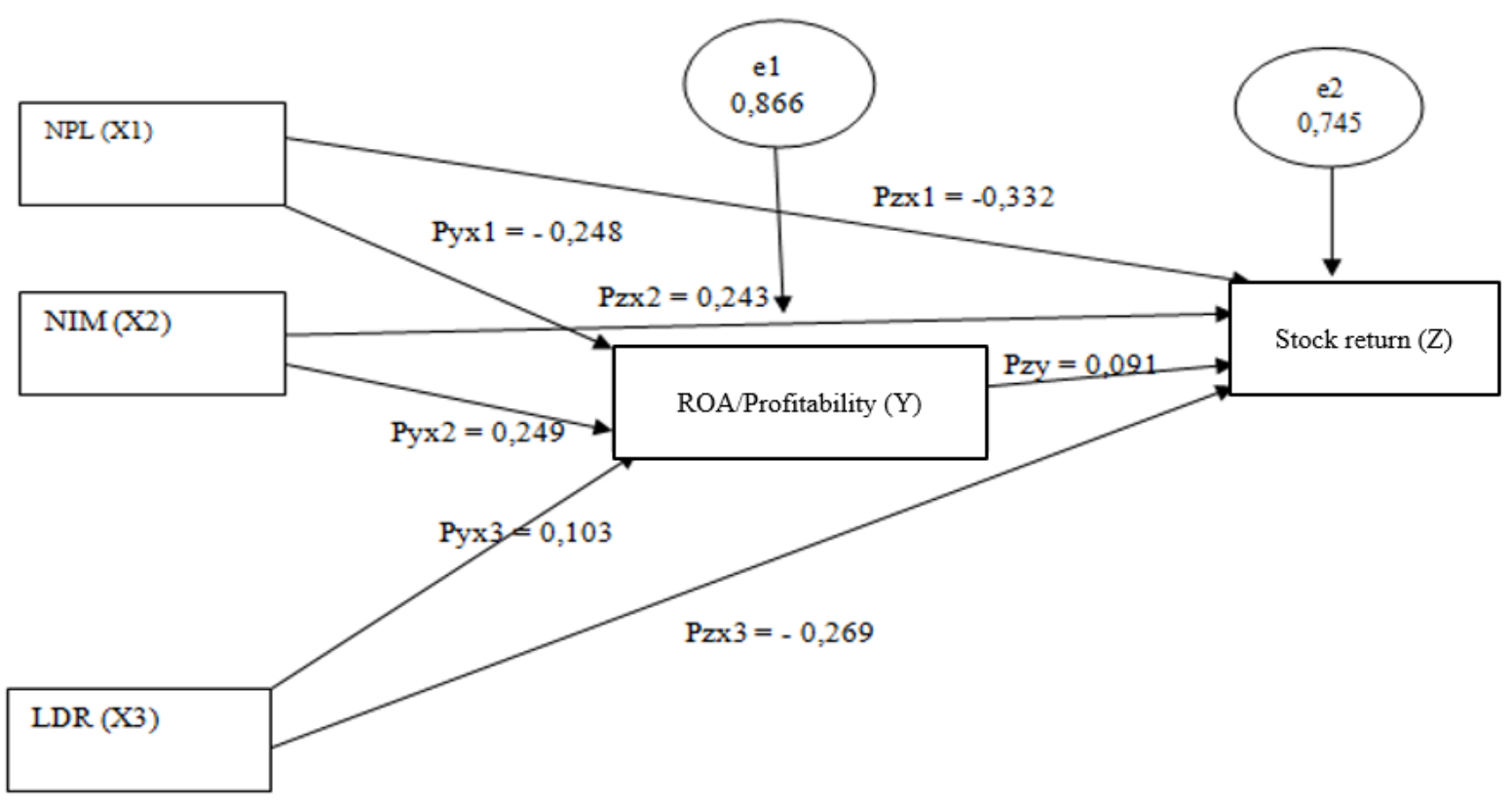

Image 2. Path Diagram

The path analysis equation above is: 


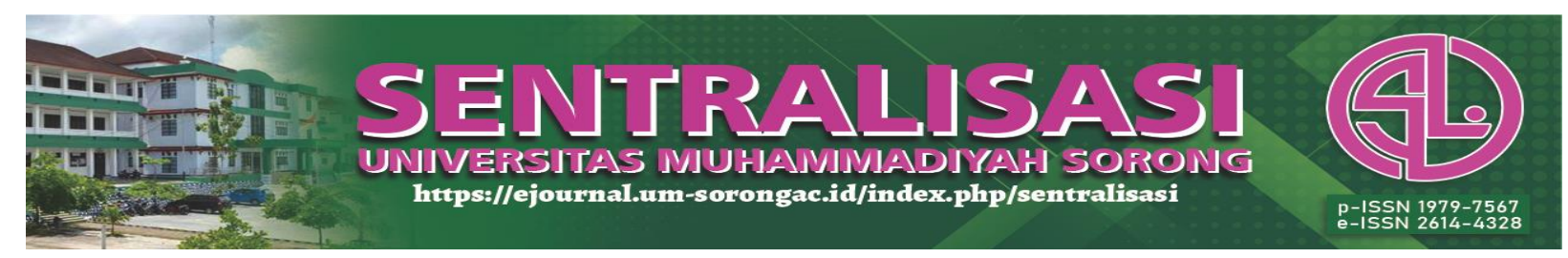

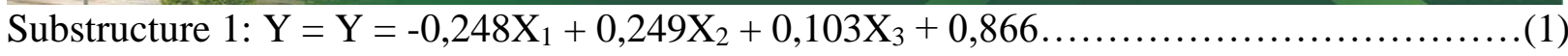

For Substructure 1, it can be seen that if the NPL value (X1) increases by 1 then the ROA (Y) value will decrease by 0.248 , if the NIM value (X2) increases by 1 then the ROA value will increase by 0.249 and if the LDR value (X3) increases by 1 , then the ROA (Y) value also increases by 0.103 and other variables apart from this study have an effect of 0.866 towards the increase or decrease in ROA.

Substructure $2: Z=-0,332 X_{1}+0,243 X_{2}-0,269 X_{3}+0,091 Y+0,745$

For Substructure 2, it can be seen that if the NPL value (X1) increases by 1 then the stock return value $(Z)$ will decrease by 0.332 , if the NIM value (X2) increases by 1 then the stock return value $(Z)$ will also increase by 0.243 , if the LDR (X3) increases by 1 , the stock return value $(Z)$ will decrease by 0.269 and if the value (Y) or ROA increases by 1 , the stock return value $(\mathrm{Z})$ will also increase by 0.091 and the increase or decrease $(\mathrm{Z})$ of stock returns is affected by other variables beyond this study by 0.745 .

\section{Partial Testing (t-test)}

Table 2. Partial Testing

\begin{tabular}{lcclc}
\hline \multicolumn{1}{c}{ Hypothesis } & t-count & t-table & p-value & Conclusion \\
\hline $\begin{array}{l}\text { NPL had an effect on } \\
\text { ROA }\end{array}$ & $-2,868$ & $\pm 1,981$ & 0,005 & significant \\
NIM had an effect on & 2,880 & $\pm 1,981$ & 0,005 & significant \\
ROA & 1,188 & $\pm 1,981$ & 0,237 & insignificant \\
$\begin{array}{l}\text { LDR had an effect on } \\
\text { ROA }\end{array}$ & $-3,985$ & $\pm 1,981$ & 0,000 & significant \\
$\begin{array}{l}\text { NPL had an effect on } \\
\text { stock return }\end{array}$ & 2,915 & $\pm 1,981$ & 0,004 & significant \\
$\begin{array}{l}\text { NIM had an effect on } \\
\text { stock return }\end{array}$ & $-3,317$ & $\pm 1,981$ & 0,001 & significant \\
$\begin{array}{l}\text { LDR had an effect on } \\
\text { stock return }\end{array}$ & 1,053 & $\pm 1,981$ & 0,294 & insignificant \\
$\begin{array}{l}\text { ROA had an effect on } \\
\text { stock return }\end{array}$ & & & \\
\hline
\end{tabular}

\section{Source: Processed data}

From table 2 above the p-value $<0.05$ indicated that the hypothesis can be accepted. The $\mathrm{t}-$ test result states that NPL had a negative effect on ROA, NIM had a positive effect on ROA, LDR had no effect on ROA, NPL had a negative effect on Stock Returns, NIM had a positive effect on stock returns, LDR had a negative effect on stock returns and ROA had no effect on stock returns.

The analysis results are as follows: 


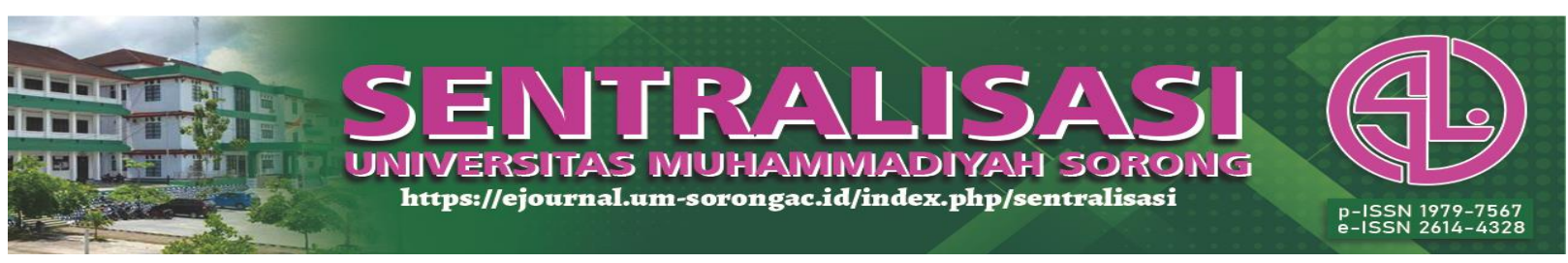

NPL Affected Profitability Level (ROA)

The partial testing based on the t-test above showed that NPL had a significant effect on the profitability level (ROA). NPL (Non-Performing Loan) is a ratio which describes the amount of risk that non-performing loans have will give an effect on the profitability level generated by banks. In addition, the negative value on the variable coefficient describes that the NPL had a negative effect on profitability, meaning that if the NPL of banks increases, the profitability level generated by banks will be smaller or less. Therefore, banking companies must be able to manage loans so that they are not at risk of bad debt and able to decrease the percentage of NPLs which will affect or increase ROA which can show good progress on company performance. This study confirmed the research results conducted by (Nadi, 2017), (Eprima et al., 2015), (Hutagalung, N. E. D and Ratnawati, 2013) who stated that NPL had a significant negative effect on ROA.

NIM Affected Profitability Level (ROA)

The partial testing based on the t-test results showed that NIM had an effect on the company's profitability. Meaning that the size of the company's profitability was affected by NIM or Net Interest Margin so that the bank's ability to generate profit from interest reflected the productivity of the bank. The variable coefficient value had a positive value, meaning that if NIM of the bank increases, the profitability level will also increase.

NIM showed the bank's ability to generate net interest and increase profitability. Consequently, a good management of earning assets can produce maximum net interest. The higher NIM shows the bank's performance, the better it is in giving loans so that it can generate higher interest income from loans, NIM which is the differences of interest received from loans minus interest payments to customers will generate net interest income which will affect the profitability level (ROA) generated by the company. This study was supported by the study conducted by (Nadi, 2017) and (Hutagalung, N. E. D and Ratnawati, 2013), and (Eprima et al, 2015) which explained that NIM had a significant positive effect on ROA.

\section{LDR Affected Profitability (ROA)}

The test results partially described that LDR had no significant effect on the profitability level (ROA), meaning that the profitability level produced by the bank was not seen from how much loan given by the bank compared to the funds received by the bank from customers, because profitability is the amount of the company's ability to generate profits, meaning that determining the amount of profitability is seen from how much banks can generate profits, not seen from the amount of LDR. This study confirmed the research conducted by (Hutagalung, N. E. D and Ratnawati, 2013) explaining that LDR had no significant effect on the profitability level (ROA).

Profitability Level (ROA) affected Stock Returns. 


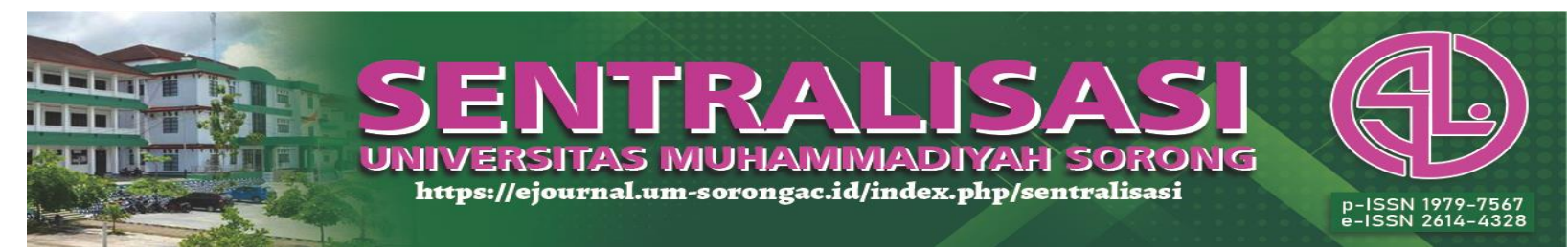

The partial testing described that ROA had no significant effect on Stock Returns. The results of this study explained that the profitability level or profit generated by the company did not have an effect on the numbers of stock returns that will be received by investors. This was because profitability was related to the received dividends and moreover the calculation of stock returns which ignored the received dividends. The market or investors, in choosing a company to invest in, do not only see how much profit a company generates, but there are other factors considered in choosing stocks that will have an impact on a company's stock returns. Usually investors in determining the sale and purchase of stock by looking at the movement of stock prices on the stock exchange every day. This research confirmed the research (Zakchona \& Sihombing, 2019) explaining that ROA had no significant effect on Stock Returns.

\section{NPL Affected Stock Returns}

The partial testing explained that NPL had a significant effect on stock returns. The value of NPL coefficient was negative for stock returns, the smaller the NPL of the banking system means the bigger the increase or return of shares because NPL ratio is a ratio that describes how much non-performing loans a bank has. A higher NPL of a bank explains poor management in organizing credit which will affect on the poor performance of the bank. If the bank performance is disturbed, it will affect the market response which causes more decreased stock returns. This study confirmed the research (Mafthuah, 2015) which stated that there was a significant negative NPL effect on stock returns. This study also confirmed the research conducted by (Muhamad, 2015) which explained that NPL had a significant effect on stock returns. This research was opposite to the research conducted by (Zakchona \& Sihombing, 2019) which stated that NPL did not significantly affect on stock returns.

\section{NIM affected Stock Returns}

The $\mathrm{T}$ test in this study explained that NIM had a significant effect on stock returns. The positive coefficient result explained that the higher NIM ratio, the higher stock returns obtained. The magnitude of NIM ratio will have an impact on increasing net interest income which will increase company profits which shows that the company's performance is good in accordance with the investment principle that investors will buy shares in companies that have good profits and will give a positive signal to the market so that the stock returns will increase. This research was contrast with the research conducted by (Zakchona \& Sihombing, 2019) which proved that NIM had no significant effect on stock returns.

\section{LDR Affected Stock Returns}

The results of the $\mathrm{T}$ test explained that LDR had a significant effect on stock returns and the coefficient value was negative, which stated that the smaller the LDR, the greater the stock 


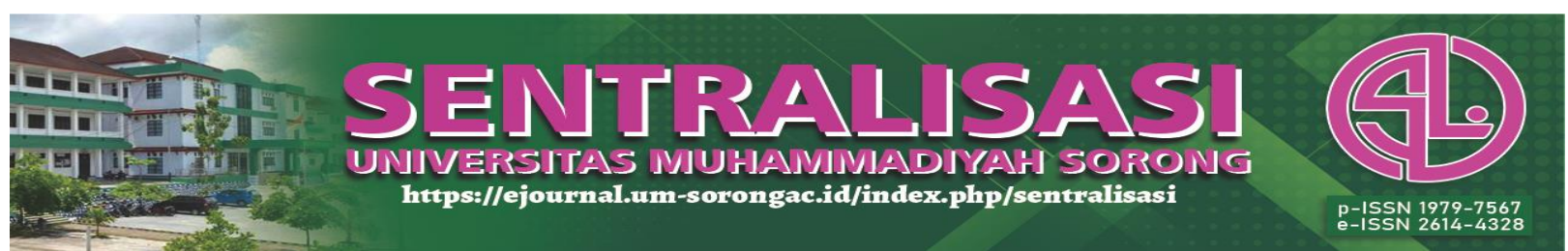

returns will be. If the LDR ratio is too big, it indicates the bank liquidity is not healthy, and vice versa, it will show the performance of the bank management. If the bank performance is declared healthy, it will have an impact on the market and many investors will invest and the stock price will also increase so that it will affect the stock returns received. So, if the LDR value of a bank is small, it will have an impact on increasing the resulting stock returns. This study confirmed the research conducted (Zakchona \& Sihombing, 2019) explaining that LDR had a significant effect on stock returns.

\section{Simultaneous Test (F Test)}

The test criteria $(\mathrm{F})$ if the value of $\mathrm{F}$ count $\geq \mathrm{F}$ table, then Ho was rejected with a significance level of 0.05 .

Table 3. Test F Results

\begin{tabular}{lcccc}
\hline \multicolumn{1}{c}{ Hypothesis testing } & F Count & F Table & Decision & Conclusion \\
\hline $\begin{array}{l}\text { There were effects of NPL, } \\
\text { NIM, LDR simultaneously }\end{array}$ & 5,999 & 2,683 & H0 rejected & Significant \\
on profitability & & & \\
There were effects of NPL, & 9,829 & 2,451 & H0 rejected & Significant \\
NIM, profitability on stock & & & \\
returns & & & & \\
\end{tabular}

Source: Processed data

Based on table 3, sub structure 1, NPL, NIM, and LDR simultaneously had an effect on profitability which means that the three variables simultaneously had an impact on the level of profitability. If one of these ratios change, it will have an impact on the changes in profitability because the three ratios can be used to assess banking performance.

In addition, for sub structure 2, NPL, NIM, LDR and profitability simultaneously had an effect on stock returns. This means that the four variables simultaneously had an effect on stock returns because these ratios were used to measure the level of health and bank performance and will affect stock returns.

\section{Intervening Test}

To figure out the effects of NPL, NIM, LDR on Stock Returns through Profitability, a sobel test was conducted.

Test criteria:

if $\mathrm{t}$-count $\geq \mathrm{t}$-table or $\mathrm{t}$-count $\leq$-t-table then $\mathrm{H}_{1}$ is accepted.

if $-\mathrm{t}$-table $<\mathrm{t}$-count $<\mathrm{t}$-table then $\mathrm{H}_{1}$ is rejected. 


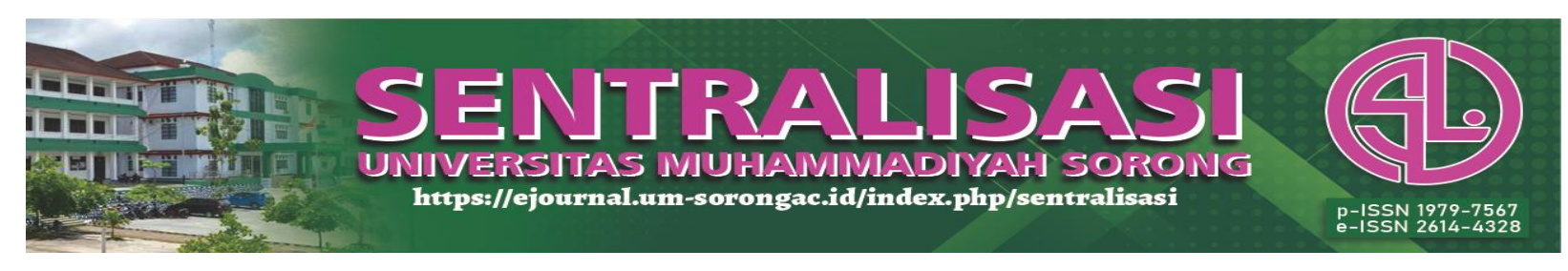

Table 4. Sobel Test Results

\begin{tabular}{lllc}
\hline \multicolumn{1}{c}{ Annotation } & t-count & t-table & conclusion \\
& & $\pm 1,981$ & insignificant \\
\hline $\begin{array}{l}\text { The effect of NPL on Stock Return } \\
\text { through profitability }\end{array}$ & $-0,004$ & $\pm 1,981$ & insignificant \\
$\begin{array}{l}\text { The effect of NIM on Stock Return } \\
\text { through profitability }\end{array}$ & 0,004 & & \\
$\begin{array}{l}\text { The effect of LDR on Stock } \\
\text { Return through profitability }\end{array}$ & 0,004 & $\pm 1,981$ & insignificant \\
\hline
\end{tabular}

Note. $\mathrm{Y}=\mathrm{M}$ (intervening)

Source : Processed Data.

Table 4 describes that NPL had no effect on Stock Returns through ROA, meaning that NPL did not have a significant effect on stock returns through profitability or in other words that profitability had no effect on NPL as an intervening variable. NIM had no significant effect on Stock Return (Z) through ROA (Y), meaning that NIM did not have a significant effect on stock returns through profitability or profitability had no effect on NIM as an intervening variable.

LDR had no significant effect on Stock Return through ROA, meaning that LDR had no significant effect on stock returns through profitability or profitability did not have an effect on LDR as an intervening variable. Based on the above results, NPL, NIM and LDR had no significant effects on stock returns $(Z)$ through ROA, it was because in this study the ROA variable partially had no effect on stock returns so that the ROA variable was weak as an intervening variable.

\section{Conclusion}

NPL partially has a significantly negative effect on the profitability level, which means that the greater the NPL of a bank, it will have an impact on the lower level of bank profitability. Meanwhile, NIM has a significantly positive effect on the profitability level, which means that the higher the NIM, which is net interest margin, it will have an effect on the higher profitability level, while LDR, which is the liquidity ratio, does not have a significant effect on the level of profitability. Meanwhile, simultaneously NPL, NIM, and LDR have a significant effect on profitability.

NPL and LDR have a significantly negative effect on stock returns, which means that the high values of NPL and LDR will affect on the smaller value of bank stock returns. For NIM, it has a significantly positive effect on stock returns, which means that if the NIM of a bank has an increase, it will have an effect on higher stock returns. The profitability level has no significant effect on stock returns. Meanwhile, NPL, NIM, LDR, and the profitability level simultaneously have a significant effect on stock returns.

Dewi Oktary 


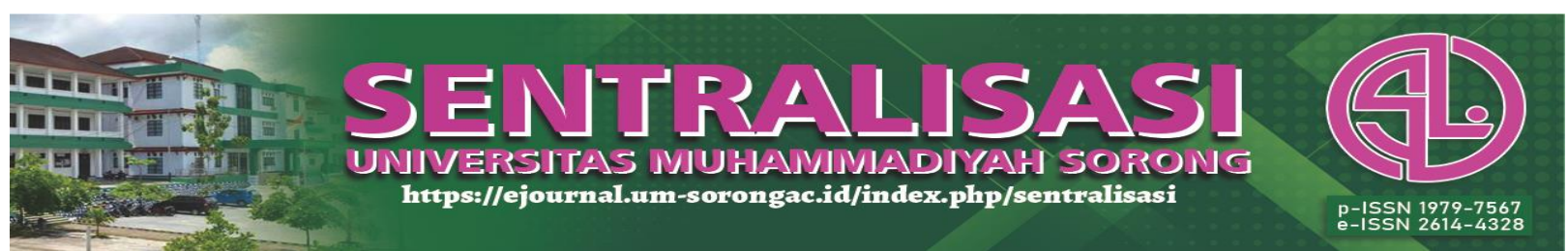

For the results of the intervening test, NPL, NIM, LDR do not have a significant effect on stock returns through the profitability level, which means that the level of profitability has no significant effect on NPL, NIM, LDR as intervening variables. This research can be used as literature to assess bank financial performance which can be used as calculation input for investment in the capital market. For further research, it is better to add more research variables and use different tools of analysis.

\section{Acknowledgement}

The researchers would like to express gratitude to DRPM KEMENRISTEKDIKTI for providing aid in the form of PDP scheme grants for 2020 fiscal year for this research.

\section{References}

Eprima, D. L., Nyoman, H. T., \& Gede, E. luh. (2015). An Analysis on The Effects of NIM, BOPO, LDR, and NPL on Profitability (A Case Study on National Private Commercial Bank Listed on Indonesia Stock Exchange in A Period of 2009-2013. E-Journal S1 Ak. Universitas Pendidikan Ganesha, 3(1). Retrieved from https://doi.org/http://dx.doi.org/10.23887/jimat.v3i1.4752

Hutagalung, N. E. D and Ratnawati, K. (2013). An Analysis on Financial Ratio on the Performance of Commercial Banks in Indonesia. Journal of Management Application Journal. Journal of Management Application, 11(1), 122-130. Retrieved from https://jurnaljam.ub.ac.id/index.php/jam/article/view/502/532

Kasmir. (2018). Banks And Other Financial Institutions Revised Edition 2014 (Revised Ed) Depok: Raja Grafindo Persada.

Maftuhah, L. (2015). An analysis of the Effects of CAR, LDR, NIM, and NPL on Stock Returns. University of Sebelas Maret. Retrieved from https://eprints.uns.ac.id/id/eprint/34748

Muhamad, N. K. (2015). The effects of CAR, NPL, and BOPO on profitability and stock returns in banks listed on the IDX in 2009-2013. Journal of Chemical Information and Modeling, 3(2), 258-269. Retrieved from https://doi.org/https://doi.org/10.35794/emba.v3i2.8530

Nadi, L. (2017). An analysis of CAR, NPL and NIM effects on Bank Profitability Listed on Indonesia Stock Exchange. Pamulang University Scientific Journal of Accounting, 4 (2), 958977. Retrieved from https://doi.org/http://dx.doi.org/10.32493/jiaup.v4i2.183

Financial Services Authority. (2019). Banking Industry Profile Report for Quarter IV 2018. Retrieved from https://www.ojk.go.id/id/kanal/perbankan/data-dan-statistik/laporan-profilindustri-perbankan/Pages/-Laporan-Profil-Industri-Perbankan-Triwulan-IV-2018.aspx

Rivai, V., Basir, S., Sudarto, S., \& Veithzal, P. A. (2013). Commercial Bank Management Banking Management From Theory to Practice (1st ed.). Jakarta: PT. Raja Grafindo Persada.

Sugiyono. (2019). Qualitative Quantitative Research Methods and $R \& D$ (Second). Bandung: Alfabeta.

Zakchona, E., \& Sihombing, P. (2019). An analysis of Financial Performance Impact on Expected Return of Listed Bank Stock in Indonesia Capital Market (2009 - 2017 Period). Journal of Entrepreneurship, Management, and Industry (JEMI), 2(1), 35-47. Retrieved from http://jurnal.bakrie.ac.id/index.php/JEMI/article/view/1847/1477 


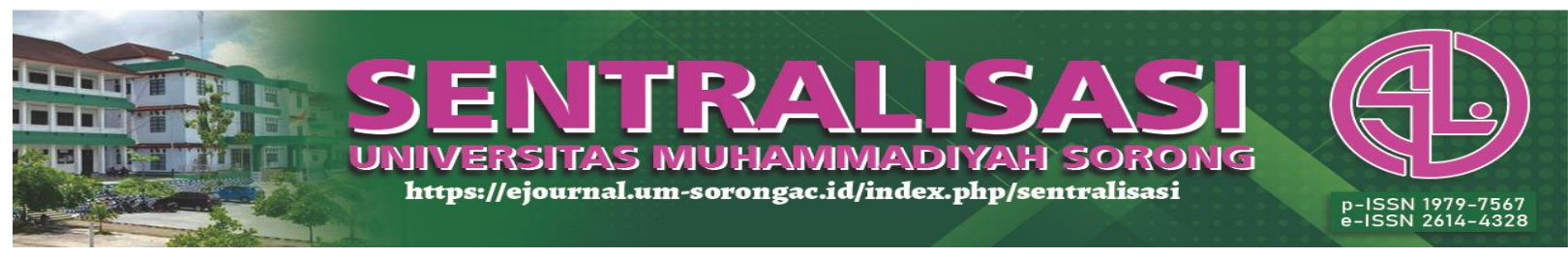

